\title{
Sesoanal Veriation in Primary Productivity from Nanded Region, Maharashtra
}

\author{
A. V. Suryawanshi \\ Dept. of Fishery Science, N.E.S .Science College, Swami Ramanand Teerth Marathwada University, Nanded. India
}

Available online at: www.isroset.org

Received: 20/Mar/2019, Accepted: 11/Apr/2019, Online: 30/Apr/2019

\begin{abstract}
Study showed that primary productivity status from site A maximum NPP was found in May (1.7 mg/L/hr), minimum in December $(0.08 \mathrm{mg} / \mathrm{L} / \mathrm{hr})$ and average NPP value was $0.50 \mathrm{mg} / \mathrm{L} / \mathrm{hr}$. GPP was maximum in $(2.3 \mathrm{mg} / \mathrm{L} / \mathrm{hr})$ in May and minimum in January $(0.2 \mathrm{mg} / \mathrm{L} / \mathrm{hr})$ average GPP value was $0.97 \mathrm{mg} / \mathrm{L} / \mathrm{hr}$. CR was maximum in December $(1.4 \mathrm{mg} / \mathrm{L} / \mathrm{hr})$ and minimum in $(0.2 \mathrm{mg} / \mathrm{L} / \mathrm{hr})$ in January. Average CR value was $0.55 \mathrm{mg} / \mathrm{L} / \mathrm{hr}$ in the year Jan 2013- Dec 2013. From site B Maximum NPP value was recorded in May $(3.45 \mathrm{mg} / \mathrm{L} / \mathrm{hr})$ and minimum in December $(0.06 \mathrm{mg} / \mathrm{L} / \mathrm{hr})$, average NPP value was $0.45 \mathrm{mg} / \mathrm{L} / \mathrm{hr}$. GPP was maximum in May $(2.03 \mathrm{mg} / \mathrm{L} / \mathrm{hr})$ and minimum in September and November $(0.2 \mathrm{mg} / \mathrm{L} / \mathrm{hr})$. Average GPP value was $0.86 \mathrm{mg} / \mathrm{L} / \mathrm{hr}$. CR was maximum in August $(1.7 \mathrm{mg} / \mathrm{L} / \mathrm{hr})$ and minimum in December $(-0.20 \mathrm{mg} / \mathrm{L} / \mathrm{hr})$. During the study period average $\mathrm{CR}$ value was $0.30 \mathrm{mg} / \mathrm{L} / \mathrm{hr}$.
\end{abstract}

Keywords- Primary Productivity, NPP, GPP, CR.

\section{INTRODUCTION}

Phytoplankton is one of the initial biological component from which the energy is transferred to higher organisms through food chain 3) thus referred as the primary producers. Primary productivity gives information about bioactivity in an ecosystem. Quantity of food produced naturally in pond is the productivity of that pond. Different physico chemical parameters are directly related to the productivity. Primary productivity is the rate at which radiant energy is stored by producers. NPP is amount of organic matter stored by producers per unit area in time. GPP is amount of organic matter synthesized by producers per unit area in time. Productivity of pond is very important for the pearl culture operation. Highly productive pond is provides good food source to the mussel. During study period maximum productivity was found in summer and minimum in winter. NPP and GPP were maximum in summer at both sites. NPP, GPP were found minimum in winter at site A and site B. Negative $\mathrm{Cr}$ value is obtained from site B. CR value from both site continuously fluctuated during study period. (2), (7).

\section{MATERIAL \& METHODS}

\section{PRIMARY PRODUCTIVITY}

Two sites were selected for the study from site A was constructed farm lake near CIDCO, Nanded. Site B was a cement tank situated in N. E.S. Science college Nanded. Water samples were collected from Jan 2013 to Feb 2014 in between 6:30 am to 9:30 am. Estimation of primary production was done by using Light and Dark bottle method as suggested by (5). Water samples were collected in dark and light bottle. Dark bottle is covered with black color polythin bag and both the bottles are tied with the help of thread and kept in water for an hour after that readings were taken. Primary productivity is calculated by using following formula.

i. $\quad$ Net Primary Productivity -

$$
\mathrm{O}_{2} \mathrm{mg} / \mathrm{L} / \mathrm{hr}=\underline{\mathrm{DI}-\mathrm{Di}}
$$

$\mathrm{hr}$

ii. Gross Primary Productivity -

$$
\mathrm{O}_{2} \mathrm{mg} / \mathrm{L} / \mathrm{hr}=\underline{\mathrm{DI}-\mathrm{Dd}}
$$

iii. Community respiration -

$$
\mathrm{O}_{2} \mathrm{mg} / \mathrm{L} / \mathrm{hr}=\underline{\mathrm{Di}-\mathrm{Dd}}
$$

Where, $\mathrm{Di}=$ Dissolved oxygen in the initial bottle in $\mathrm{mg} / \mathrm{L}$.

$\mathrm{DI}=$ Dissolve oxygen in light bottle in $\mathrm{mg} / \mathrm{L}$.

$\mathrm{Dd}=$ Dissolve oxygen in dark bottle in $\mathrm{mg} / \mathrm{L}$.

$\mathrm{hr}=$ Duration of exposure period in hrs.

Statistical Analysis

$\mathrm{T}$ - Test was used to test the significant difference between sampling stations

for assessing physical chemical parameters of water. Paired

$\mathrm{T}$ - test is used to estimate 
changes in growth of mussels. It was carried out with the help of MINITAD software.

\section{RESULT \& DISCUSSION}

Primary productivity was studied from Jan 2013 to Dec 2013 from site A and site B and expressed as $\mathrm{mg} / \mathrm{L} / \mathrm{hr}$

\section{Site A}

Maximum NPP was found in May $(1.7 \mathrm{mg} / \mathrm{L} / \mathrm{hr})$, minimum in December $(0.08 \mathrm{mg} / \mathrm{L} / \mathrm{hr})$ and average NPP value was $0.50 \mathrm{mg} / \mathrm{L} / \mathrm{hr}$. GPP was maximum in $(2.3 \mathrm{mg} / \mathrm{L} / \mathrm{hr})$ in May and minimum in January $(0.2 \mathrm{mg} / \mathrm{L} / \mathrm{hr})$ average GPP value was $0.97 \mathrm{mg} / \mathrm{L} / \mathrm{hr}$. CR was maximum in December (1.4 $\mathrm{mg} / \mathrm{L} / \mathrm{hr})$ and minimum in $(0.2 \mathrm{mg} / \mathrm{L} / \mathrm{hr})$ in January. Average CR value was $0.55 \mathrm{mg} / \mathrm{L} / \mathrm{hr}$ in the year Jan 2013Dec 2013. (Table No. 1.1)

\section{Site B}

Maximum NPP value was recorded in May $(3.45 \mathrm{mg} / \mathrm{L} / \mathrm{hr}$ ) and minimum in December $(0.06 \mathrm{mg} / \mathrm{L} / \mathrm{hr})$, average NPP value was $0.45 \mathrm{mg} / \mathrm{L} / \mathrm{hr}$. GPP was maximum in May $(2.03$ $\mathrm{mg} / \mathrm{L} / \mathrm{hr})$ and minimum in September and November $(0.2$ $\mathrm{mg} / \mathrm{L} / \mathrm{hr}$ ). Average GPP value was $0.86 \mathrm{mg} / \mathrm{L} / \mathrm{hr}$. CR was maximum in August $(1.7 \mathrm{mg} / \mathrm{L} / \mathrm{hr})$ and minimum in December $(-0.20 \mathrm{mg} / \mathrm{L} / \mathrm{hr})$. During the study period average CR value was $0.30 \mathrm{mg} / \mathrm{L} / \mathrm{hr}$. (Table No. 1.1)

\section{T-test for NPP}

T-test for NPP showed the average NPP of both site is same (Table No. 1.2)

\section{T-test for GPP}

T-test for GPP showed the average GPP of both site is same. (Table No. 1.3)

\section{T-test for CR}

T-test for CR showed average CR of both the site is same (Table No. 1.4).

\section{Discussion}

Quantity of food produced naturally in pond is the productivity of that pond. Different physico chemical parameters are directly related to the productivity. Primary productivity is the rate at which radiant energy is stored by producers. NPP is amount of organic matter stored by producers per unit area in time. GPP is amount of organic matter synthesized by producers per unit area in time. Productivity of pond is very important for the aquatic life. Highly productive pond is provides good food source to the aquatic animals. During study period maximum productivity was found maximum in summer and minimum in winter. NPP and GPP were maximum in summer at both sites. NPP, GPP were found minimum in winter at site A and site B. Negative CR value is obtained from site B. CR value from both site continuously fluctuated during study period.
Table No 1.1 - shows month wise variations in primary productivity from Jan - Dec during the year 2013 at site $A$ and site $B$.

\begin{tabular}{|c|c|c|c|c|c|c|}
\hline \multirow{2}{*}{ Month } & \multicolumn{3}{|c|}{ Site A mg/L/hr } & \multicolumn{3}{c|}{ Site B mg/L/hr } \\
\cline { 2 - 7 } & NPP & GPP & CR & NPP & GPP & CR \\
\hline Jan & 0.2 & 0.2 & 0.2 & 0.2 & 0.4 & 0.2 \\
\hline Feb & 0.2 & 0.6 & 0.4 & 0.2 & 0.41 & 0.21 \\
\hline Mar & 1.0 & 2.0 & 1.0 & 0.21 & 0.41 & 0.2 \\
\hline Apr & 1.0 & 1.3 & 0.3 & 0.46 & 1.3 & -0.26 \\
\hline May & 1.7 & 2.3 & 1.2 & 3.45 & 2.03 & -1.42 \\
\hline Jun & 0.5 & 0.8 & 0.6 & 0.21 & 0.61 & 0.4 \\
\hline July & 0.4 & 0.8 & 0.4 & 0.21 & 0.61 & 0.4 \\
\hline Aug & 0.4 & 0.6 & 0.2 & 0.2 & 1.9 & 1.7 \\
\hline Sep & 0.2 & 0.6 & 0.4 & 0.1 & 0.2 & 1.2 \\
\hline Oct & 0.2 & 0.4 & 0.2 & 0.1 & 1.2 & 1.1 \\
\hline Nov & 0.2 & 0.6 & 0.4 & 0.1 & 0.2 & 0.1 \\
\hline Dec & 0.08 & 1.5 & 1.4 & 0.06 & 1.14 & -0.205 \\
\hline Average & $\mathbf{0 . 5 0}$ & $\mathbf{0 . 9 7}$ & $\mathbf{0 . 5 5}$ & $\mathbf{0 . 4 5}$ & $\mathbf{0 . 8 6}$ & $\mathbf{0 . 3 0}$ \\
\hline
\end{tabular}

NPP- Net primary productivity, GPP- Gross primary productivity, CR-Community respiration

Table No 1.2 - shows T-test for net primary productivity at site $A$ and site B from Jan to Dec 2013.

\begin{tabular}{|l|c|c|c|c|}
\hline & $\mathbf{N}$ & Mean & St Dev & SE Mean \\
\hline NPP Site A & 12 & 0.507 & 0.485 & 0.14 \\
\hline NPP Site B & 12 & 0.458 & 0.948 & 0.27 \\
\hline
\end{tabular}

Table No 1.3 - shows T-test for gross primary productivity at site A and site B from Jan to Dec 2013.

\begin{tabular}{|c|c|c|c|c|}
\hline & $\mathbf{N}$ & Mean & St Dev & SE Mean \\
\hline GPP Site A & 12 & 0.975 & 0.657 & 0.19 \\
\hline GPP Site B & 12 & 0.868 & 0.636 & 0.18 \\
\hline
\end{tabular}

Table No 1.4 - shows T-test for community respiration at site A and site B from Jan to Dec 2013.

\begin{tabular}{|l|c|c|c|c|}
\hline & $\mathbf{N}$ & Mean & St Dev & SE Mean \\
\hline CR Site A & 12 & 0.558 & 0.412 & 0.12 \\
\hline CR Site B & 12 & 0.302 & 0.799 & 0.23 \\
\hline
\end{tabular}

N-total number, St Dev- standard deviations, SE Meansample estimated mean.

\section{ACKNOWEDGEMENT}

Authors are thankful to Principal N. E. S. Science College Nanded for providing Laboratory and Library

\section{REFERENCES}

[1]. APHA. Standard Methods for the Examination of Water and Wastewater. 19th ed., American Public Health Association, New York, 1143, 1995. 
[2]. Gajanan K. Sontakke and Satish S. Mokashe. Seasonal variation in primary productivity of two freshwater lakes of Aurangabad district, Maharashtra, India. International Journal of Fauna and Biological Studies Vol. 1, No. 6, pp. 07-10, 2014.

[3]. Pasternak K, Kasza H. Chemical reactions and primary production of phytoplankton in the warmed water of the Rybrik reservoir Acta. Hydrobiol; Vol. 20, No. 4, pp. 305-322, 1979.

[4]. Prabhakar V.M, Vaidya S.P, Garud V.S and Swain K.K. Trend in Primary Production in Khdakwasla Reservoir. 13th World Lake Conference, Wuhan, China 2009.
[5]. Trivedi, R.K. and P.K. Goel. Chemical and biological methods for water pollution studies. Environmental Publications, Aligarh, 1986.

[6]. Touliabah H. S. Relations between fertilization and phytoplankton composition and productivity in serw fish farm. M. Sc. Girl Coll. Ain Shams Univ. p-213, 1992.

[7]. Westlake D.F. Comparison of Plant Productivity. Botanical Research 25b 385-425, 1963. 